\title{
Evaluating the Adoption of IFRS by the Economies of Developing Countries: Case Study of Jordanian Firms
}

\author{
Dr. Tareq Hammad Almubaydeen \\ Associate Professor/ Department of Accounting/ Zarqa University/JORDAN \\ Vice deen of the Faculty of Economics and Administrative Sciences
}

\begin{abstract}
As globalisation and international trade facilitate economies to have access and impact over one's financial and nonfinancial environments, it becomes necessary for such countries to produce information that is globally understandable. Development of IFRS pays emphasis over this by stating accounting methods based upon articulated standards. However, established by the West, IFRS ignores some of the potential factors obstructing full adoption within developing economies. The current study pays attention to one such economy, namely Jordan, highlighting internal as well as external elements that discourage the adoption of IFRS and hence harmonisation of international financial information. The review-based methodology allows insights from several scholars providing not only a complete list of factors hindering the switch but also the implications why firms may consider switching to an internationally acceptable and high-quality method.
\end{abstract}

Keywords: IFRS adoption, Developing Economies, Jordan.

\section{Introduction}

The integration and dependence of countries over one another, allowing easy cross-frontier movements of capital and other resources require internationally admissible accounting and administration standards. Adopting such similar reporting principle obliterates the need to translate financial disclosures and statements of different firms operating in different countries into an analogous standard to facilitate comparisons, easy understanding for all stakeholder groups, and undertaking similar entries for each transaction. Consequently, The International Accounting Standards Board (IASB), established a single set pattern of high quality, internationally implementable and comprehensible fiscal reporting standards founded upon articulated principles formally known as International Financial Accounting Standards (IFRS) (Cai \& Wong, 2010).

The change from GAAP or any other legal accounting format to internationally preferred IFRS is evident within many continents. This eventual adoption, while ran smoothly for developed nations with already-transparent financial markets, caused several complications for the developing ones. Hence, literature produced by many scholars discuss the procedures, advantages, disadvantages and impact over the financial data produced by firms with respect to developing nations including Jordan, Romania, and other nations included in the MENA region (Klibi \& Kossentini, 2014; Jackling, Howieson \& Natoli, 2012; Temiz \& Gulec, 2017).

IFRS is currently practised by firms in over 115 countries, while a large number of other countries have set a calendar for complete adoption of IFRS. Although initially, the standard was only approved by developed nations, many developing countries have come under the wave of IFRS endorsement. The shift from un-recognised standards to IFRS has acknowledged as the most widespread accounting standards change in the entire reporting history hence encouraging scholars to examine its impacts and changes it brings substantially (Christensen, Hail \& Leuz, 2013; Ahmed, Neel \& Wang, 2013). The reason for this switch on a massive scale is perhaps due to several benefits IFRS provides such as improving the quality of financial reporting, parallelism, facilitating users to undertake informed decisions through fair presentations, easy harmonisation of finance-based data, and enhanced potentiality to secure cross-country listings (Amanamah, 2017; Chebaane \& Othman, 2014). For firms that have operations in more than one country, adopting a corresponding pattern to report economic transactions allows improved management of international operations and activities, whether financial or non-financial, along with significant reductions in the cost of capital appointed and increased foreign investments (Faraj \& Akbar, 2010; He, Wong \& Young, 2012). Such factors make IFRS adoption justified.

However, despite the numerous advantages that IFRS yields assisting firms in financial reporting, certain disadvantages and limitations hinder its true impact. This is particularly accurate when it comes to developing economies or for firms that deal with non-IFRS countries. It is believed that adoption of IFRS can be seen as diffusing a nation's culture into the standards followed by in the West, which may be resented on religious, political or even social grounds. 
The complexity of the standards, especially for nations that lack the knowledge, skills and adequate education, may be seen as another challenge (Masoud, 2014). For firms or nations that have been following non-IFRS standards will have to undertake significant costs and undergo strenuous changes in regulations making the adoption process even more difficult than it already is (Michas, 2010).

The above-mentioned advantages and challenges of IFRS concentrate upon general problems or benefits that occur for most firms. However, there exists lack of literature solely focussing for developing economies like Jordan and their responses when it comes to IFRS adoption. The current research study aims to discuss the factors affecting and the implications of IFRS adoption in the emerging economies, with a specific focus on Jordan.

Jordan is characterised as one of the few countries that were able to develop public shareholding as early as the 1930s (Al-Farah, Abbadi \& Al Shaar, 2015). Since then, the economy developed a series of major enterprises followed by the establishment of a financial market in the 1970s, namely, Amman Financial Market (AFM). The development paved the encouragement to adopt a generally acceptable pattern to undertake all monetary and financial transactions. This constitutes as the subject of the literature review and analysis, that is evaluating reporting standards of firms in Jordan and their adoption of IFRS over time.

\section{Methodology}

To address the research objective of studying IFRS adoption in the Jordanian firms and contribute to existing literature, the study pursues qualitative review-based methodology. More specifically, the research study performs a narrative review of studies that have empirically examined the case of IFRS adoption in Jordan. Due to scarce evidence on the subject related to Jordan, the research is able to review 8 studies, published during the period 2009-2019. The study presents the findings in a review table, highlighting the author(s), year and the methodology. Moreover, the researcher ensures the credibility of the findings and considers relevant ethical principles.

\section{Literature Review}

When adopting a new arrangement at a strategic level, whether voluntary or compulsory, a well-thought-out change management system is required with equipped with adequate resources. The new arrangement will be subject to numerous elements that will either pave the way for change or hinder the overall change process. According to Gernon and Wallace (1995), the accounting environment and its change is influenced by institutional, societal, and individual dimensions that may be internal or external. Poudel et al., (2014) identifies that adoption of IFRS and the change in the accounting environment is not necessarily encouraged by the need of natives but instead foisted by donor institutions like IMF (International Monetary Fund) and World Bank.

To understand influences and changes in accounting standards practised by firms, Roberts, Weetman and Gordan (2002) presented a detailed development structure. This is illustrated in figure 1. The structure is established upon the premise that any accounting standard adopted will be subject to contextual elements, especially when it comes to developing economies like Jordan. 


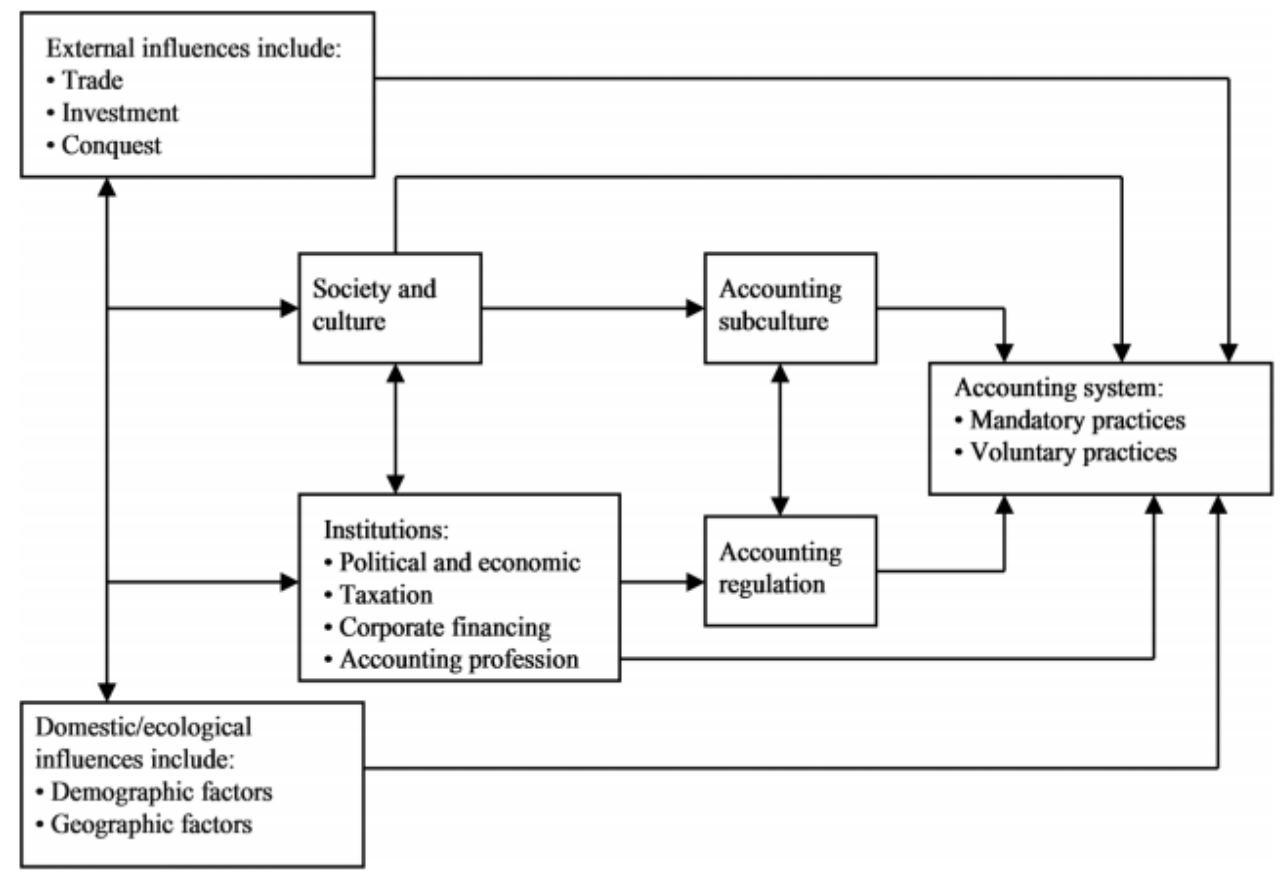

Figure 1: Accounting standards development structure. Source: Roberts et al. (2002)

Al-Htaybat (2018) states that tailor-made accounting standards of each region are unable to satisfy foreign stakeholder requirements in terms of decision making, restraining economies to attract international investors. For developing economies, this becomes a significant obstacle for growth. Furthermore, accounting operation catastrophe's example Enron, Lehman Brothers and WorldCom in the past decade have affected the trust of stakeholders in financial reporting practices. Hence, the emphasis has been paid to the adoption of an analogous accounting standard, namely, IFRS in countries all over the globe. While these provide comprehensive disclosures and reduce the risk of fraud, some attributes of developing economies act as competitive forces, these include high levels of uncertainty, extrinsic and intrinsic environmental pressures such as governmental, technological, education and training and political burdens. Hence, moving these nations towards IFRS adoption can be seen as a global remedy for their current financial reporting problems. Al-Akra, Ali and Marashdeh (2009) too highlight that in the context of Jordan, dealing with external factors including taxation, cultural considerations, businesses legal status and ownership, religion was a major issue.

Jordan became a member of the IASC (International Accounting Standards Committee) in 1988. The Jordanian economy is steadily moving towards improving external trade relations combined with efforts to open the nations towards several free trade unions. Consequent to such expansions, King Abdullah, along with the government, feels the need to build a favourable business climate. To do so, a new legal framework was imposed making it mandatory for all listed companies on the Jordanian Stock Exchange to implement IFRS in 2002 (Al-Htaybat 2014). Hence, unlike many other nations, the development of IFRS has been continuing for almost two decades, providing adequate insights into the entire process. The establishment of Companies Law No.22 made it compulsory for the Jordan Securities Commission, all financial intermediaries controlled by the Central Bank of Jordan and Jordan Insurance Commission to now publish full disclosures in accordance with the laws stated under IFRS. This wave encouraged all firms operating within the economy to comply with the full version of IFRS and hence improve disclosure quality significantly. Similar to this, Cotter, Tarca and Wee (2012) explored that reliability of financial data and accuracy of predicted forecasts improved after the adoption of IFRS in the case of Jordan firms.

The literature presented by Masoud (2017) examines tertiary, and industrial-based firms listed on the Amman Stock Exchange from 2002 to 2013 to study the effects of compulsory IFRS implementation. The investigation concludes that forecasted earnings dispersion reduced overtime. This result is evident because as financial information becomes more transparent, analysts are able to produce high-quality and accurate forecasts, reducing the occurrence of errors. These findings run parallel to those of Horton, Serafeim and Serafeim (2013), that conducted its study over 8000 firms located in different parts of the world. The findings suggest that IFRS earnings enhanced forecast accuracy and increased confidence in financial environments when compared with GAAP earnings. The study produced by Humeedat (2019) was referred to examine the impact of IFRS adoption in terms of accounting conservatism and accuracy of financial statements for commercial banks operating in Jordan. 
During the Pre-IFRS tenure, that ranges from 2000-2008, accounting conservatism lacked accuracy while the latter period ranging from 2009-2017 exhibited higher levels of verification and conservatism, proving the effectiveness for IFRS adoption. On the other hand, Al-Khadash and Abdullatif (2009) identified that as the IFRS is established over fair accounting of all assets, liabilities, profits and losses, for a developing country like Jordan which has been in contrast, valuing these transactions at cost values find it rather difficult to immediately adapt to such significant changes. After the change, Jordan commercial and investment financial intermediaries found that due to fair valuation, their earnings per share (EPS)proved to be significantly high. However, it does report that as Jordan is a developing nation and deals with inefficient financial markets, using the fair value principle does distort short-term incomes, misguiding investors.

\section{Results and Findings}

Based on the above literature review, the study presents the following key findings, i.e. factors affecting and implications of IFRS adoption in Jordan. Here, the majority of the reviewed studies are quantitative.

Table - 1: Literature Review Findings

\begin{tabular}{|c|c|c|c|}
\hline Year & Author & Methodology & Key Findings \\
\hline 2012 & $\begin{array}{l}\text { Mardini, } \\
\text { Crawford \& } \\
\text { Power }\end{array}$ & $\begin{array}{l}\text { Quantitative } \\
\text { Research Method } \\
\text { supported by a } \\
\text { disclosure index } \\
\text { checklist. }\end{array}$ & $\begin{array}{l}\text { After the adoption of IFRS standards, specifically IFRS } \\
8 \text {, the number of segments disclosed within financial } \\
\text { statements rose significantly. }\end{array}$ \\
\hline 2014 & $\begin{array}{l}\text { Abu Risheh } \\
\& \text { Al-Saeed }\end{array}$ & $\begin{array}{l}\text { Quantitative } \\
\text { Research Study }\end{array}$ & $\begin{array}{l}\text { IFRS implementation while brings several benefits for } 91 \\
\text { listed companies in Jordan, it led towards a sharp rise in } \\
\text { audit fees. While other factors too played a major role in } \\
\text { influencing audit and accounting surcharges such as firm } \\
\text { size, trade receivables and goodwill, changing to IFRS } \\
\text { was identified as the most significant one. }\end{array}$ \\
\hline 2018 & Al-Htaybat & $\begin{array}{l}\text { Interpretive and } \\
\text { Qualitative } \\
\text { Methodology }\end{array}$ & $\begin{array}{l}\text { The study concludes that as Jordan was the first emerging } \\
\text { nation to adopt IRFS in the Middle East, external } \\
\text { conditions exert high pressure when compared to internal } \\
\text { reluctances. Furthermore, institutional push, country-wide } \\
\text { volatility, firms' efforts to improve disclosures and } \\
\text { resolve corporate deterrents were seen as major elements } \\
\text { influencing IFRS adoption. }\end{array}$ \\
\hline 2017 & Masoud & $\begin{array}{l}\text { Quantitative } \\
\text { Approach with } \\
\text { Regression Model }\end{array}$ & $\begin{array}{l}\text { As Jordan listed firms comply towards mandatory IFRS } \\
\text { adoption, predicted earning forecast become more } \\
\text { accurate and show a reduction in error and dispersion. } \\
\text { This is because with IFRS compiled financial statements; } \\
\text { analysts are able to generate precise data of future } \\
\text { earnings and profits. }\end{array}$ \\
\hline 2012 & Saaydah & $\begin{array}{l}\text { Quantitative, Cross- } \\
\text { Sectional Model }\end{array}$ & $\begin{array}{l}\text { The study finds that while literature argues that using fair } \\
\text { valuation principle under IFRS adoption yields an } \\
\text { accurate market value of the corporation, the findings } \\
\text { generate no such conclusions. One possible explanation, } \\
\text { regarding the conclusions, is that firms are yet to apply } \\
\text { IFRS completely. }\end{array}$ \\
\hline 2009 & $\begin{array}{l}\text { Al-Akra, Ali } \\
\& \text { Marashdeh }\end{array}$ & Review based & $\begin{array}{l}\text { IFRS adoption in Jordan was mainly encouraged by its } \\
\text { colonial past. Also, privatisation has played a major role } \\
\text { in moving the economy towards becoming more } \\
\text { internationally recognised by the implementation of } \\
\text { IFRS. The growing private sector advanced modern } \\
\text { disclosure regulations to attract international investors } \\
\text { paving the way for IFRS. }\end{array}$ \\
\hline 2014 & Kutum & Qualitative Analysis & $\begin{array}{l}\text { The compliance of IFRS within banks in Jordan instructs } \\
\text { to provide risk disclosures in their annual reports. } \\
\text { However, most banks yet do not comply with this and } \\
\text { provide absolute minimum information in the voluntary }\end{array}$ \\
\hline
\end{tabular}


risk disclosure field. This makes the information provided at the end of the year of very little use for stakeholders. Therefore, IFRS remains inadequate in providing relevant financial data.

2019 Alshyoukh \& Quantitative

The literature concludes that several changes in Jordanian Manaf Research firms occurred post-IFRS adoption. This includes reduced value relevance recoded as per book value of capital, more relevant and accurate earnings value yields, along with increased earnings persistence. However, earnings management and timely loss reorganisation was lower post-IFRS implementation. The study hence concludes opposite to the stated beliefs that IFRS improve accounting quality and information.

\section{Conclusion}

The introduction of IFRS by IASB brought a sudden yet much-required change of harmonisation of cross-country firms' financial statements, forecast and other data, making it easier for stakeholders to employ. As the previously used GAAP method proved to be ineffective in times where globalisation has allowed investors to participate in crosscountry trading activities, IFRS solved not only this but many other problems as well ranging from comparability to fair presentations. However, as IFRS is a standardised accounting reporting system created in some of the most developed nations of the world, it tends to lack effectiveness of many of its processes in undeveloped or developing nations, in this case, Jordan. This is due to external constraints including unavailability of relevant skilled individuals to carry out accounting transactions as stated by the new standard, lack of accurate and transparent information occurring due to bubble economies, high switching costs and inefficient financial markets.

In contrast, it is true that despite above-mentioned hindrances, corporations in Jordan are transacting to an analogous, world-wide accepted accounting standard. Some of the most obvious reasons for this change is the improvement in the fair valuation of their earnings per share figures, a high degree of verification, accuracy and conservatism in financial data, able to generate accurate predicted forecast making it easier for analysts, reduction in the risk of fraud and dispersion. It proves that despite external constraints, the overall switch does lead to an enhanced financial environment that holds the potential to attract foreign investments.

\section{References}

Abu Risheh, K. E., \& Al-Saeed, M. T. A. (2014). The Impact of IFRS Adoption on Audit Fees: Evidence from Jordan. Accounting \& Management Information Systems/Contabilitate si Informatica de Gestiune, 13(3).

Ahmed, A. S., Neel, M., \& Wang, D. (2013). Does mandatory adoption of IFRS improve accounting quality? Preliminary evidence. Contemporary Accounting Research, 30(4), 1344-1372.

Al-Akra, M., Ali, M. J., \& Marashdeh, O. (2009). Development of accounting regulation in Jordan. The International Journal of Accounting, 44(2), 163-186.

Al-Farah, A., Abbadi, S., \& Al Shaar, E. (2015). The accounting and auditing profession in Jordan: Its origin and development. Developing Country Studies, 5(8), 167-179.

Al-Htaybat, K. (2018). IFRS adoption in emerging markets: the case of Jordan. Australian Accounting Review, 28(1), $28-47$.

Al-Htaybat, K. A. (2014). Codification theory is a gateway for setting mandatory reporting requirements in emerging economies. International Journal of Economics and Finance, 6(11), 21-35.

Al-Khadash, H., \& Abdullatif, M. (2009). Consequences of fair value accounting for financial instruments in the developing countries: The case of the banking sector in Jordan. Jordan journal of business administration, 5(4), 533-551.

Alshyoukh, F. M., \& Manaf, K. B. A. (2019). The Effects of Mandatory IFRS Adoption on Accounting Information Quality: Empirical Evidence from Jordan. Social Science and Humanities Journal, 1395-1415.

Amanamah, R. B. (2017). Benefits and Challenges of International Financial Reporting Standards Adoption in Ghana: Accounts and Business Managers" Perspective. International Journal of Accounting and Financial Reporting, 7(2), 178-193.

Cai, F., \& Wong, H. (2010). The effect of IFRS adoption on global market integration. International Business \& Economics Research Journal (IBER), 9(10). 
Chebaane, S. and Othman, H.B., 2014. The impact of IFRS adoption on the value relevance of earnings and book value of equity: the case of emerging markets in African and Asian regions. Procedia-Social and Behavioral Sciences, 145 , pp.70-80.

Christensen, H. B., Hail, L., \& Leuz, C. (2013). Mandatory IFRS reporting and changes in enforcement. Journal of Accounting and Economics, 56(2-3), 147-177.

Cormier, D., Ledoux, M. J., \& Villeneuve, G. (2015). Value relevance of discretionary accruals under environmental uncertainty: the incidence of IFRS and the country's legal regime. International Journal of Accounting, Auditing and Performance Evaluation, 11(2), 161-187.

Cotter, J., Tarca, A., \& Wee, M. (2012). IFRS adoption and analysts' earnings forecasts: Australian evidence. Accounting \& Finance, 52(2), 395-419.

Faraj, S., \& Akbar, S. (2010). An empirical investigation of the Libyan audit market: perceptions of auditor's independence. Journal for Global Business Advancement, 3(2), 133-154.

Gernon, H., \& Wallace, R. O. (1995). International accounting research: A review of its ecology, contending theories and methodologies. Journal of Accounting Literature, 14, 54.

He, X., Wong, T. J., \& Young, D. (2012). Challenges for implementation of fair value accounting in emerging markets: Evidence from China. Contemporary Accounting Research, 29(2), 538-562.

Horton, J., Serafeim, G., \& Serafeim, I. (2013). Does mandatory IFRS adoption improve the information environment? Contemporary accounting research, 30(1), 388-423.

Humeedat, M. M. (2019). Changes in Accounting Conservatism in Pre-and Post-IFRS Adoption in Jordan. Changes, 10(4).

Jackling, B., Howieson, B., \& Natoli, R. (2012). Some implications of IFRS adoption for accounting education. Australian Accounting Review, 22(4), 331-340.

Klibi, M. F., \& Kossentini, A. (2014). Does the adoption of IFRS promote emerging stock markets development? Evidence from MENA countries. International Journal of Accounting, Auditing and Performance Evaluation, 10(3), 279-298.

Kutum, I. (2014). Investigating Voluntary Risk Disclosure: The Case of Jordanian Banks. Journal of Modern Accounting and Auditing, 10(12), 1153-1166.

Mardini, G. H., Crawford, L., \& Power, D. M. (2012). The impact of IFRS 8 on disclosure practices of Jordanian listed companies. Journal of Accounting in Emerging Economies.

Masoud, N. (2014). Libya's IAS/IFRS Adoption and Accounting Quality: What Lessons from the European Union Experience. International journal of accounting and financial reporting, 4(1), 118.

Masoud, N. (2017). The effects of mandatory IFRS adoption on financial analysts' forecast: Evidence from Jordan. Cogent Business \& Management, 4(1), 1290331.

Michas, P. (2010). Auditing in emerging market countries: does it matter?. Working Paper, University of Missouri.

Roberts, C., Weetman, P., \& Gordon, P. (2002). International Financial Accounting.

Temiz, H., \& Güleç, Ö. F. (2017). Mandatory adoption of IFRS in emerging markets: the case of Turkey. 